\title{
Evaluation of the influence of UV radiation and sodium hypochlorite on the shelf life
}

\section{of strawberries}

\author{
Avaliação da influência dla radiação UV e do hipoclorito de sódlio na vida de prateleira de morangos \\ Evaluación de la influencia de la radiación UV y el hipoclorito de sodio en la vida útil de las fresas
}

Received: 08/11/2021 | Reviewed: 08/18/2021 | Accept: 08/24/2021 | Published: 08/25/2021

\author{
Amanda Eri Anze \\ ORCID: https://orcid.org/0000-0002-5824-6375 \\ Universidade Federal do Triângulo Mineiro, Brazil \\ E-mail: d201810430@uftm.edu.br \\ Ana Claudia Granato Malpass \\ ORCID: https://orcid.org/0000-0001-6487-1225 \\ Universidade Federal do Triângulo Mineiro, Brazil \\ E-mail: ana.malpass@uftm.edu.br \\ Geoffroy Roger Pointer Malpass \\ ORCID: https://orcid.org/0000-0002-0036-5750 \\ Universidade Federal do Triângulo Mineiro, Brazil \\ E-mail: geoffroy.malpass@uftm.edu.br \\ Mônica Hitomi Okura \\ ORCID: https://orcid.org/0000-0002-9875-9378 \\ Universidade Federal do Triângulo Mineiro, Brazil \\ E-mail: monica.okura@uftm.edu.br
}

\begin{abstract}
It is common to combine methods to increase the shelf life of a raw material or product. In this study, we sought to understand the relationship between ultraviolet (UV) radiation and sodium hypochlorite ( $\mathrm{NaOCl})$ in attenuating the proliferation of fungus and its deteriorating effect on strawberries. The UV light intensities of 125, 250 and 400 Watts (W) and sodium hypochlorite were tested in concentrations $0.5,1.0$ and $1.5 \mathrm{ppm}$. The strawberries were sprayed with sodium hypochlorite solutions and then kept for 1 minute in UV light chambers, to then be stored in transparent sealed plastic containers. The strawberry samples with the longest life were those that were sprayed with 0.5 and $1.0 \mathrm{ppm}$ sodium hypochlorite solution combined with exposure to $125 \mathrm{~W}$ UV light. These samples had a shelf-life extension of about five days compared to strawberries without any kind of treatment. Thus, it is possible to state that this combination is efficient in cleaning the fruit without causing damage.
\end{abstract}

Keywords: Fungal contamination; Sanitization; Shelf life.

\section{Resumo}

É comum combinarmos métodos para aumentar a vida de prateleira de uma matéria-prima ou produto. Nessa pesquisa, procurou-se entender a relação da radiação ultravioleta (UV) com o hipoclorito de sódio $(\mathrm{NaOCl})$ na atenuação da proliferação do fungo e seu efeito deteriorante em morangos. Foram testadas as concentrações de luz UV de 125, 250 e 400 Watts (W) e de hipoclorito de sódio nas concentrações 0,5, 1.0 e 1,5 ppm. Os morangos foram borrifados com soluções de hipoclorito de sódio e, em seguida, mantidos por cerca de um minuto dentro de câmaras de luz UV, para então, serem armazenados em recipientes plásticos transparentes com tampa. As amostras de morango com maior longevidade foram as que foram borrifadas com solução 0,5 e 1,0 ppm de hipoclorito de sódio combinadas com a exposição à luz UV de $125 \mathrm{~W}$. Essas amostras tiveram um prolongamento de vida de prateleira de cerca de cinco dias a mais em comparação com os morangos sem qualquer tipo de tratamento. Dessa forma é possível afirmar que essa combinação é eficiente na higienização do fruto sem ocasionar danos devido ao calor.

Palavras-chave: Contaminação fúngica; Sanitização; Vida de prateleira.

\section{Resumen}

Es común combinar métodos para aumentar la vida útil de una materia prima o producto. En esta investigación, buscamos comprender la relación entre la radiación ultravioleta (UV) y el hipoclorito de sodio $(\mathrm{NaOCl})$ en la atenuación de la proliferación del hongo y su efecto de deterioro en las fresas. Las concentraciones de luz ultravioleta de 125,250 y 400 vatios (W) e hipoclorito de sodio se probaron en concentraciones de 0,5, 1,0 y 1,5 ppm. Las fresas se rociaron con soluciones de hipoclorito de sodio y luego se mantuvieron durante aproximadamente un minuto en cámaras de luz ultravioleta, para luego ser almacenadas en recipientes de plástico transparente con tapa. Las muestras de fresa con mayor vida útil fueron aquellas que fueron rociadas con solución de hipoclorito de sodio de 0.5 y $1.0 \mathrm{ppm}$ combinada con exposición a luz UV de $125 \mathrm{~W}$. Estas muestras tuvieron una extensión de vida útil de 
aproximadamente cinco días o más en comparación con las fresas sin ningún tipo de tratamiento. Así se puede afirmar que esta combinación es eficaz para limpiar la fruta sin provocar daños por calor.

Palabras clave: Contaminación por hongos; Higienización; Duración.

\section{Introduction}

Fruits are a fundamental part of the human diet, as they provide vitamins, minerals, carbohydrates and fibers, in addition to containing minimal amounts of fat and protein. According to the WHO (World Health Organization), the low consumption of fruits and vegetables is among the main risk factors for the development of chronic non-communicable diseases (Who, 2003), such as: cardiovascular diseases and certain types of digestive system neoplasms. One of the challenges in introducing a greater amount of fruit into eating habits is to increase the shelf life. This is true as fruits decay rapidly due to their low resistance to mechanical shock, non-ideal temperatures, high water activity and sensitivity to traditional sterilization treatments.

Unfortunatelly, during the pandemic time of Covid-19, a consumption decay of fresh fruits and vegetables was noticed due to the decrease of daily shopping: the need of quarantine made many individuals prefer to buy foods with longer shelf-lives, according to Berno et al. (2020). This situation could've been better if minimally processed foods were more explored in the food industry.

Despite the obstacles, the trade in fruits and vegetables is very active. According to the Brazilian Association of Exporting Producers of Fruits and Derivatives (Abrafrutas, 2019), the strawberry crop resulted in the commercialization of R\$35 million of this fruit in 2019 in Brazil, with a production of around 6000 tons. Also, the United Nations (UN) General Assembly designated the year of 2021 as the International Year of Fruits and Vegetables, wich means that UN is dedicating 2021 to encourage healthy life styles, to promote the consumption of fruits and vegetables and waste reduction (Brazil UN, 2020).

Strawberries are pseudo-fruits, rich in vitamins and widely used by the food industry, but they are perishable and have low post-harvest longevity due to their thin epidermis, large percentage of water, high metabolism (Cantillano, 2012) and their sensitivity to non-ideal temperatures. In addition, there is a likelihood of contamination by fungi.

Considering this, minimally processed fruits (MPF) are defined as fruits that have been physically modified (for example, by cutting), but that keeps their fresh state (Ifpa, 2001). MPF have gained greater space in the market for being closer to the fresh fruit, being nutritious, presenting high quality, greater convenience and microbiological safety. Thus, MPF better meet consumer expectations and avoid economic losses due to food disposal. In other words, it is important to improve the means of increasing the shelf life of fresh strawberries (a more effective sterilization, for example) instead of by ultraprocessing means.

Sodium hypochlorite $(\mathrm{NaOCl})$ is considered the most used sanitizing agent in Brazil for having oxidizing, bleaching and disinfectant properties, drinking water disinfection, industrial effluent treatment, swimming pool treatment, hospital disinfection, sanitary water production, fruit washing and vegetables, in addition to acting as an intermediary in the production of various chemical products (Silva, 2007). It reacts with water to produce hypochlorous acid ( $\mathrm{HOCl}$ ) and hypochlorite ions $\left(\mathrm{OCl}^{-}\right)$, which are the oxidizing species that exert effects on microorganisms (Resende et al., 2009). Despite the efficiency of $\mathrm{NaClO}$, it can effect the health of the consumer, due to the presence of chlorinated derivatives (Nascimento et al., 2003), residues of the substance on the surface of the fruit (Beuchat et al., 1998) and the creation of toxic compounds such as trihalomethanes (Allende et al., 2009). In addition, chlorine species are considered to be highly toxic to aquatic organisms; due to their basic character and can cause environmental alterations (Fispq, 2018). In addition, the use of sanitizers is harmful to the environment owing to the high consumption of water (Casani et al., 2004). Despite the fact that chlorine species present antimicrobial potential, it is interesting to reduce their use in favor of sustainability and consumer requirements for products 
with characteristics closer to the natural.

The second method under study is radiation from ultraviolet lamps, considered an emerging technology for sterilization, but already approved to be used as a disinfectant for food surfaces (Fda, 2011). Although this effect was discovered in 1801 by the scientist Johan Ritter and its germicidal effect was evidenced in 1878, the first processing units were only built in 1955 in Switzerland and Austria (Aguiar et al., 2002). In addition, UV radiation does not produce chemical residues, has no legal restrictions and extensive worker protection equipment is not required (Yousef \& Marth, 1998; Wong et al., 1998), it can penetrate transparent surfaces (e.g. water, air and polyethylene) depending on its wavelength, does not affect the sensory or nutritional characteristics of the food, the UV process can also provide food products with better and fresher characteristics (Salcedo et al., 2007).

For example, a study by Manzocco et al. (2011) in which UV light was applied to apple slices and these showed reduced microbial growth, darkening and flavor change compared to the control samples, as the radiation inactivated microorganisms and enzymes, in addition to creating a kind of "protective film", which also had the function of preventing dehydration. There are also studies with satisfactory results with apples (Wilson et al., 1997) in the packaging line to reduce post-harvest losses; decontamination of drinking water (Bolton, 2010; Hijnen; Beerendonk; Medema, 2006; Sonntag \& Schuchmann, 1992; Templeton; Hofmann; Andrews, 2006); minimally processed papaya and lettuce (Bachelli, 2016), minimally processed melon (Amaral, 2010), among others. Despite all the benefits, low doses of UV light, which can be supported by strawberries, may be insufficient to inactivate microorganisms.

The present study aims to study the combined techniques of chlorine species and UV irradiation to extend the shelf life of minimally processed strawberries. Based on these arguments, the main advantages of this mixed sterilization technique are understood: first, the reduction of risks to the consumer's health; second, avoid the disposal of chlorinated compounds in the environment and waste of water; finally, make the most of the antimicrobial capacity of UV irradiation without damaging food.

\section{Methodology}

\subsection{Sampling}

The strawberries were purchased at a market in the city of Uberaba for testing. All strawberries were chosen and placed in individual transparent plastic pots with lids, weighed individually and stored at room temperature and without exposure to sunlight.

Seven samples were considered: the strawberry that did not undergo any type of treatment (control), the strawberries only sprayed with sodium hypochlorite in concentrations $0.5 ; 1.0$ and 1.5 and o strawberries subjected to uv light of 125,250 and $400 \mathrm{~W}$.

\subsection{Sodium Hypochlorite $x$ Intensity of UV light}

The sodium hypochlorite concentration was set at 0.5 (A); 1.0 (B) and 1.5 (C) ppm and uv light in 125 (D), 250 (E) and $400(\mathrm{~F}) \mathrm{W}$. The entire experiment standardized the time in $1 \mathrm{~min}$ (Table 1).

Table 1. Identification of the experiment established by sodium hypochlorite concentration by UV light radiation.

\begin{tabular}{ccc}
\hline-1 & 0 & 1 \\
\hline$A D$ & $B D$ & $C D$ \\
$A E$ & $B E$ & $C E$ \\
$A F$ & $B F$ & $C F$ \\
\hline
\end{tabular}

The total number of sodium hypochlorite and UV combinations was nine. However, we must rememrre that each value was also tested alone. Source: Authors (2020). 
From these values, combinations between the two sterilization methods were made and these were applied to different strawberries. First the sodium hypochlorite was sprayed on the strawberry, then it was placed in a chamber with the UV light on for 1 minute.

\subsection{Microscopy technique}

A digital USB microscope (Innovation Beyond Imagination) was used to observe the strawberries and capture images. The strawberries were monitored daily from 0 to 10 days after treatment.

\subsection{UV lamps}

Three separate high pressure Hg (OSRAM) UV sources were used:125, 250 and $400 \mathrm{~W}$.

\section{Results and Discussion}

The control sample without any type of treatment and the samples treated only with sodium hypochlorite were all discarded by the $5^{\text {th }}$ day of observation. This indicates that, $\mathrm{NaClO}$ used in isolation, even in different concentrations, proved to be ineffective for the preservation.of strawberries. These results are similar to the control samples submitted to only to UV irradiation as all were discarded by the $5^{\text {th }}$ day. It is understood that the isolated use of the UV or sodium hypochlorite is insufficient to extend the shelf life of the strawberry, even when a higher light intensity is applied, which probably damages the fruit's surface due to heat, or a higher concentration of $\mathrm{NaClO}$ (Table 2).

On the other hand, the low concentration of $\mathrm{NaClO}(0.5 \mathrm{ppm})$ together with the least potent $\mathrm{UV}$ sourcet $(125 \mathrm{~W})$ extended the shelf life of the strawberry by about five days. The same observation applies to the sample sprayed with $1.0 \mathrm{ppm}$ $\mathrm{NaOCl}$ and exposed to $125 \mathrm{~W}$ UV light. The combination of $1.5 \mathrm{ppm}$ and $125 \mathrm{~W}$ also managed to maintain the strawberry until the 5th day, but the results were better with lower concentrations of $\mathrm{NaClO}$.

The samples submitted to 250 or $400 \mathrm{~W}$ UV sources, regardless of whether they were combined with the $\mathrm{NaClO}$ or not, had better for maintaining the quality of the strawberries compared to the control samples, but the strawberries were all discarded before the $8^{\text {th }}$ day of observation. It is likely that the heat generated by the more intense lamps combined with the sodium hypochlorite affects the tissue of the strawberry, making this combination less efficient compared to using the $125 \mathrm{~W}$ source (Table 2).

For comparison, a study by Amaral (2010) demonstrates that different methods for conserving minimally processed yellow melons were tested. It was demonstrated that the separate application of UV-C and $\mathrm{NaClO}$ were not efficient in reducing contamination of molds and yeasts. Another study, by Franco (2019), showed that the combination of UV-C and $\mathrm{NaClO}$ can be successfully used to extend the shelf-life of minimally processed bananas (microbiological and sensorial analysis). Those results are similar to the analysis strawberries in the present article.

Bachelli's (2016) confirms that radiation is more effective in reducing the microbial population in minimally processed papaya than $\mathrm{NaClO}$. In addition, other researchers have shown that lower doses of UV-C can be effective in controlling pathogens, for example, in minimally processed lettuce (Pandrangi \& Laborde, 2004; Bachelli, 2016). Finally, Zu et al. (2009) also demonstrated that UV-C radiation in minimally processed pineapples helps to reduce molds and yeasts, in addition to total coliforms. It is worth mentioning that the all the studies covered may have suffered from disparities due to the type of UV lamp source employed. 
Research, Society and Development, v. 10, n. 11, e134101119311, 2021

(CC BY 4.0) | ISSN 2525-3409 | DOI: http://dx.doi.org/10.33448/rsd-v10i11.19311

Table 2. Analysis of strawberry samples during the 10 days of observation.

\begin{tabular}{|c|c|c|c|c|c|c|}
\hline Samples & $1^{\circ}$ day & $3^{\circ}$ day & $5^{\circ}$ day & $8^{\circ}$ day & $10^{\circ}$ day & Comments \\
\hline $\begin{array}{c}\text { Control } 1 \text { (without sodium } \\
\text { hypochlorite and without UV) }\end{array}$ & & & & $\begin{array}{l}\text { Discarded } \\
\text { Strawberry }\end{array}$ & $\begin{array}{l}\text { Discarded } \\
\text { Strawberry }\end{array}$ & $\begin{array}{l}\text { Sample in good initial condition, showed } \\
\text { the first sign of deterioration around the } \\
\text { third day. Contaminated and discarded on } \\
\text { the fifth day. }\end{array}$ \\
\hline $\begin{array}{c}\text { Control } 2 \\
\text { (0.5 ppm sodium hypochlorite) }\end{array}$ & & & & $\begin{array}{l}\text { Discarded } \\
\text { Strawberry }\end{array}$ & $\begin{array}{l}\text { Discarded } \\
\text { Strawberry }\end{array}$ & $\begin{array}{l}\text { Sample in good initial condition, showed } \\
\text { the first sign of deterioration around the } \\
\text { second day. Contaminated and discarded } \\
\text { on the fifth day. }\end{array}$ \\
\hline $\begin{array}{c}\text { Control } 3 \text { (sodium hypochlorite at } 1 \\
\text { ppm) }\end{array}$ & & & & $\begin{array}{l}\text { Discarded } \\
\text { Strawberry }\end{array}$ & $\begin{array}{l}\text { Discarded } \\
\text { Strawberry }\end{array}$ & $\begin{array}{l}\text { Sample in good initial condition, showed } \\
\text { the first sign of deterioration around the } \\
\text { third day. Contaminated and discarded on } \\
\text { the fifth day. }\end{array}$ \\
\hline $\begin{array}{l}\text { Control } 4 \text { (sodium hypochlorite at } \\
1.5 \mathrm{ppm} \text { ) }\end{array}$ & & & & $\begin{array}{l}\text { Discarded } \\
\text { Strawberry }\end{array}$ & $\begin{array}{l}\text { Discarded } \\
\text { Strawberry }\end{array}$ & $\begin{array}{l}\text { Sample in good initial condition, showed } \\
\text { the first sign of deterioration around the } \\
\text { third day. Contaminated and discarded on } \\
\text { the fifth day. }\end{array}$ \\
\hline
\end{tabular}


Research, Society and Development, v. 10, n. 11, e134101119311, 2021

(CC BY 4.0) | ISSN 2525-3409 | DOI: http://dx.doi.org/10.33448/rsd-v10i11.19311

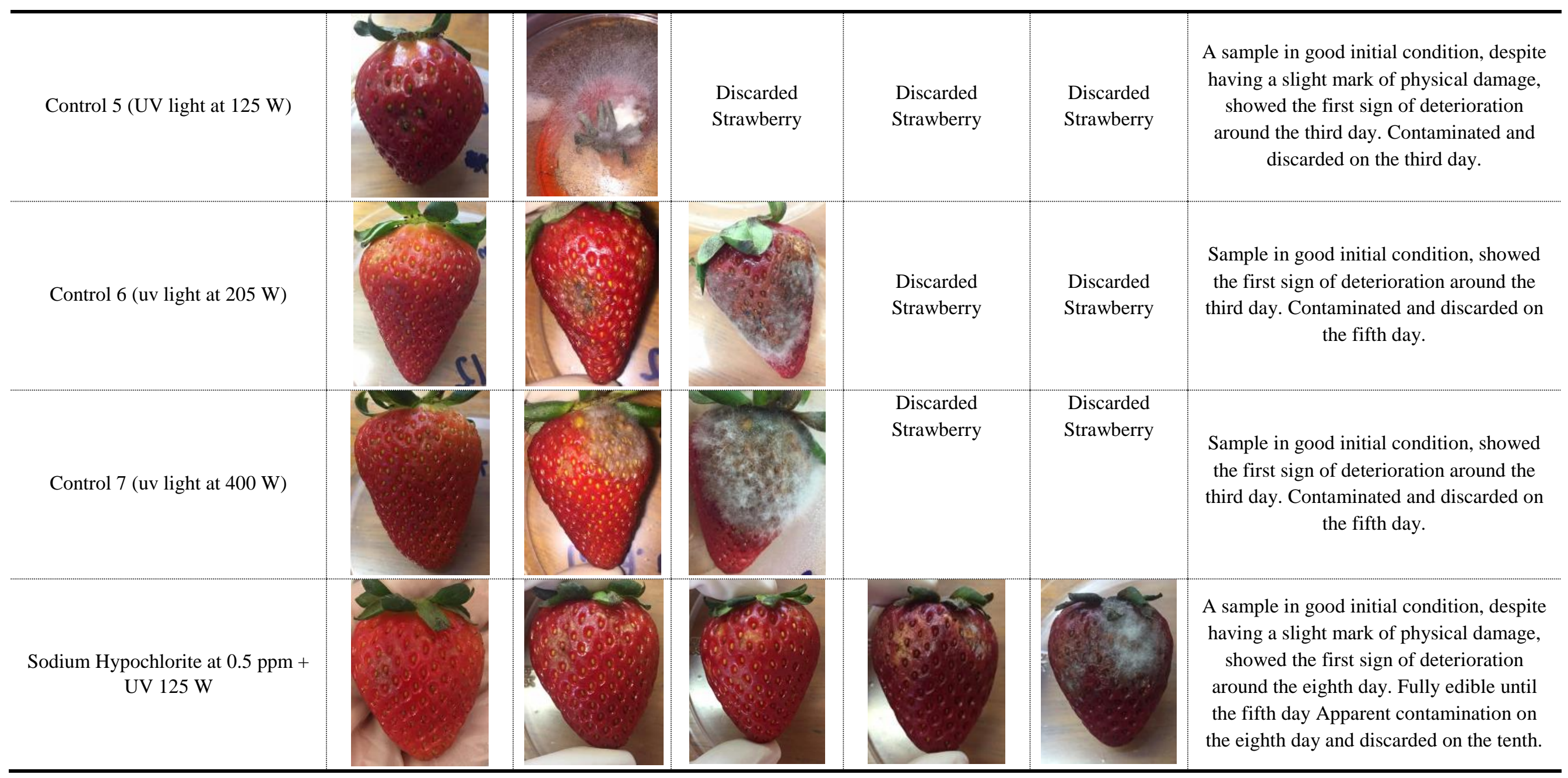


Research, Society and Development, v. 10, n. 11, e134101119311, 2021

(CC BY 4.0) | ISSN 2525-3409 | DOI: http://dx.doi.org/10.33448/rsd-v10i11.19311

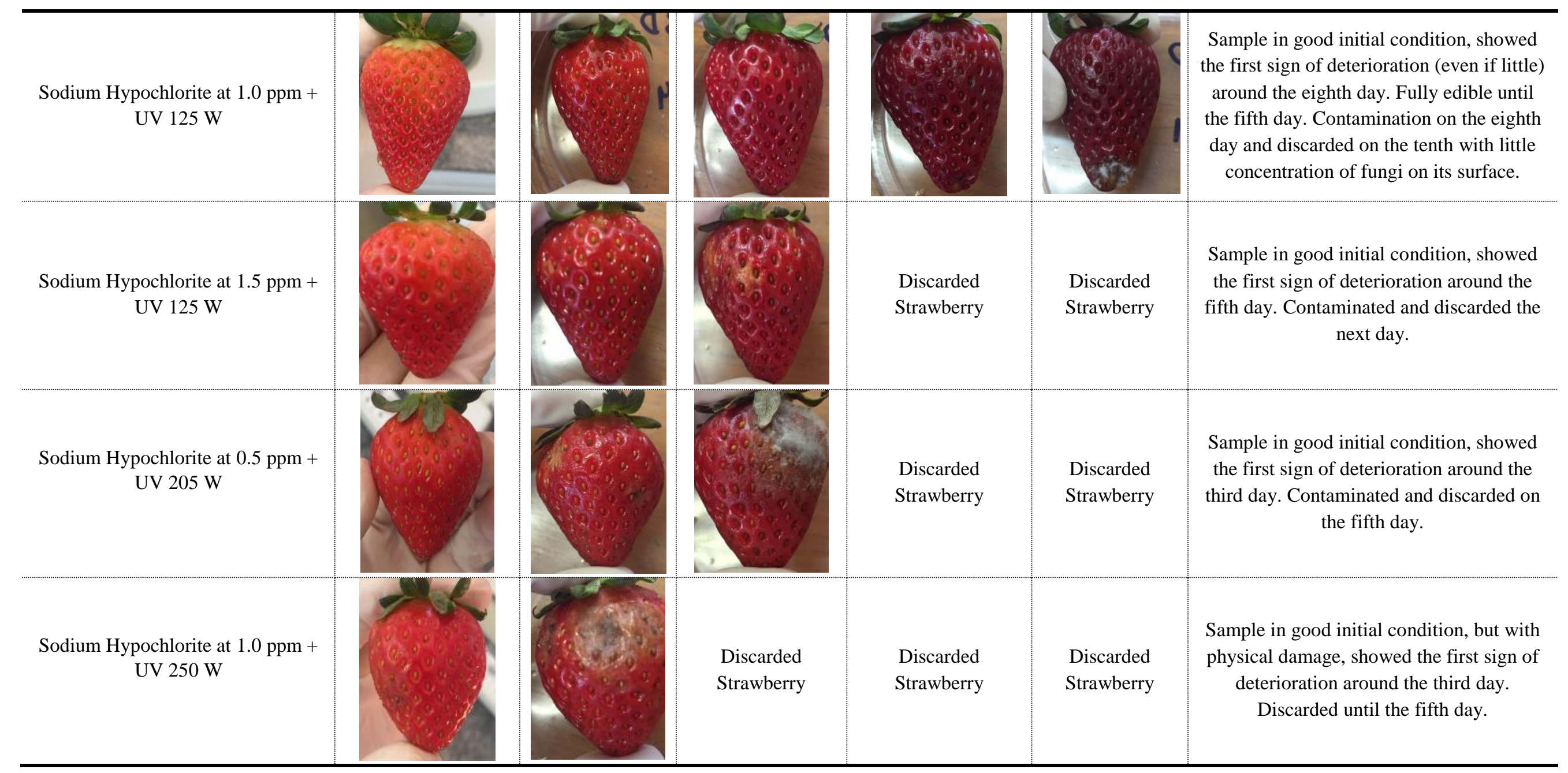


Research, Society and Development, v. 10, n. 11, e134101119311, 2021

(CC BY 4.0) | ISSN 2525-3409 | DOI: http://dx.doi.org/10.33448/rsd-v10i11.19311

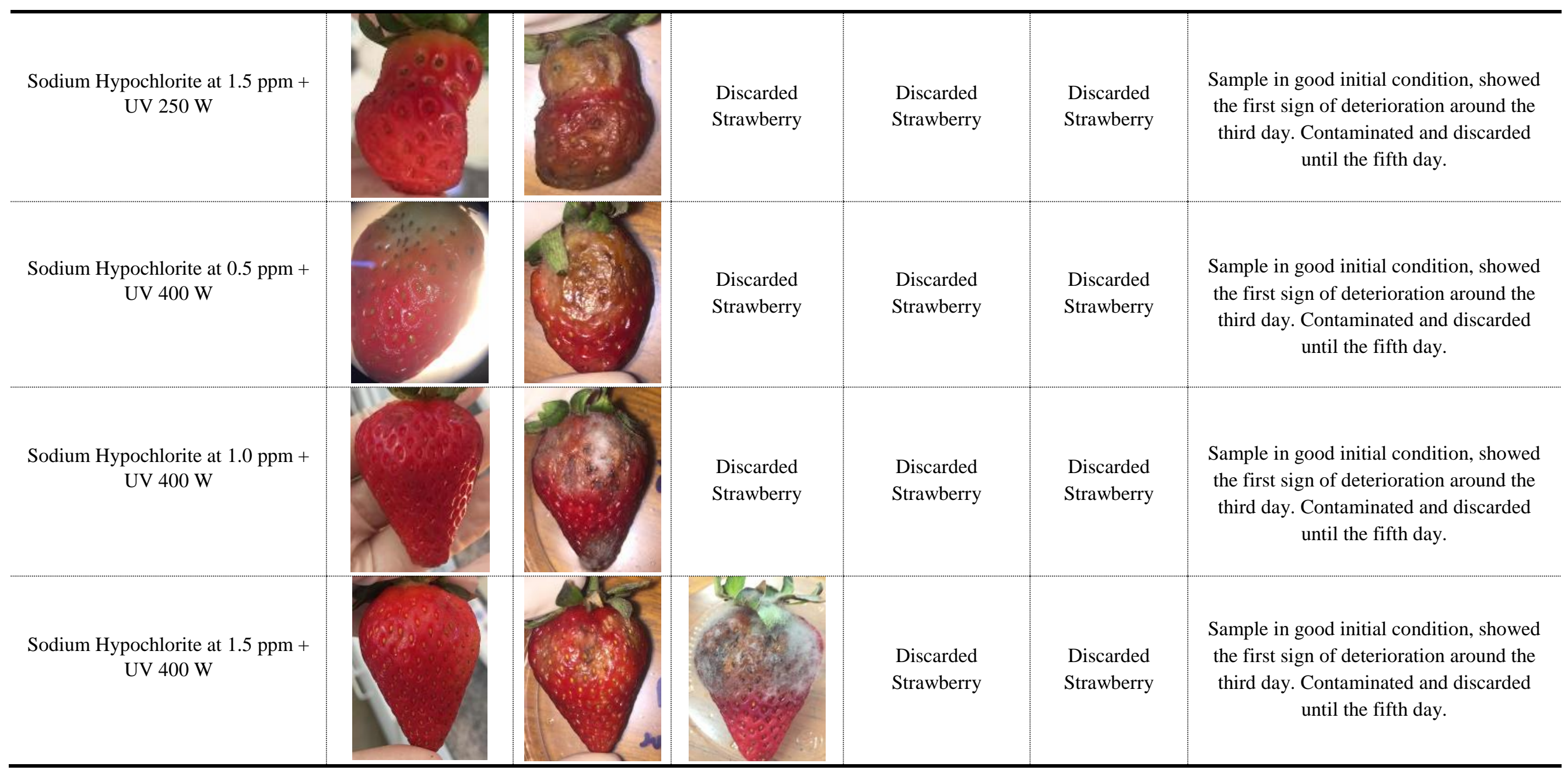

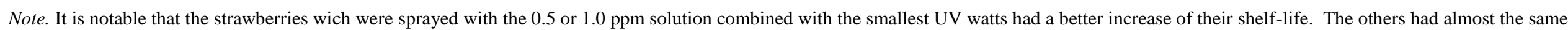
duration as the non treated strawberry. Source: Authors (2020). 


\section{Conclusion}

An increase in the shelf life of strawberries was obtained, which were submitted to the combined treatment of sodium hypochlorite (concentration of $0.5 \mathrm{ppm}$ or $1.0 \mathrm{ppm}$ ) with the UV irradiation of lesser intensity of five days in relation to the control sample. These strawberries were well preserved until the eighth day of observation. The control samples, both those in which no treatment was applied and those which were subjected to non-mixed treatments, were all discarded due to deterioration by the fifth day of analysis, at the latest. It can also be observed that the samples exposed to UV irradiation of greater intensity were possibly damaged due to the thermosensitivity of the fruit. The results of this study can be compared to others in terms of proving UV light as a promising sterilizer in the food industry, despite small disparities due to the individuality of each study.

For future researches, it is recommended to combine the sterilization methods with different storage ways, once both temperature and humidity can be important factors to increase the minimally processed products shelf life, according to J. Silva (2019). It would be important as well to study the development of other microorganisms (for example, Salmonella sp.), and the correct implementation of the Good Manufacturing Process (GMP) to avoid them (Souza, 2020), or at least to keep them in acceptable concentration levels.

\section{Acknowledgments}

The authors would like to thank FAPEMIG, CNPq and CAPES.

\section{References}

Amaral, R. D. A. (2010). Utilização de água ozonizada e radiação ultravioleta C na sanitização de melão minimamente processado. Dissertação (mestrado) Universidade Estadual de Campinas, Faculdade de Engenharia Agrícola. http://repositorio.unicamp.br/handle/REPOSIP/256953

ABRAFRUTAS. (2019). Safra do morango deve movimentar R\$35 milhões em 2019. Associação Brasileira dos Produtores Exportadores de Frutas e Derivados (ABRAFRUTAS). Asa Norte Brasília/ DF. https://abrafrutas.org/2019/09/03/safra-do-morango-deve-movimentar-r-35-milhoes-em-2019/

Bachelli, M. L. B. (2016). Avaliação da radiação ultravioleta c e água ozonizada para sanitização de alface e mamão minimamente processados. Tese (doutorado) - Universidade Estadual de Campinas, Faculdade de Engenharia Agrícola, Campinas, SP. http://www.repositorio.unicam p.br/handle/REPOSIP/319246

Bastos, M. S. R. (2006). Frutas minimamente processadas: aspectos de qualidade e segurança. Embrapa Agroindústria Tropical. http://www.agencia.cnptia.embrapa.br/Repositorio/frutasminimamenteprocessadas_000fdejd97n02wx5eo0a2ndxyb8wg7w1.pdf

Braga, C. M. (2018). Aplicação de Radiação Ultravioleta na Inativação de Microrganismos Deteriorantes de Alimentos. Tese (doutorado) - Universidade Federal de Santa Catarina, Florianópolis, SC. https://repositorio.ufsc.br/handle/123456789/193492

Cantillano, R. F. Árvore do conhecimento: Morango. Agência Embrapa de Informação Tecnológica (Ageitec). https://www.agencia.cnptia.embrapa.br/gestor/morango/arvore/CONT000fmxotm4c02wyiv8065610dp5n4a1k.html

Coelho, C.C.S., et al. (2015). Ozonização como tecnologia pós-colheita na conservação de frutas e hortaliças: Uma revisão. Rev. Bras. Eng. Agríc. Ambient.. http://ref.scielo.org/j2vvss

Indústria Química LTDA (2018). Ficha de Informação de Segurança do Produto Químico (FISPQ) do Hipoclorito de Sódio. http://www.grupohidromar.com.br/wp-content/themes/hidromar/download/FISPQ-Hipoclorito-de-sodio.pdf

Nascimento, A. R. et al. (2002). Sanitização de saladas in natura oferecidas em restaurantes self-service de São Luis, MA. Ver. Higiene Alimentar. SP. https://pesquisa.bvsalud.org/portal/resource/pt/lil-307784

Resende, A. et al. (2009). Influência do hipoclorito de sódio como fungicida na absorção de cálcio e silício pela soja. Scientia Agrária Paranaensis. http://erevista.unioeste.br/index.php/scientiaagraria/article/view/3829/2985.

Sousa, D. D. P. et al. (2019). Treatment of real dairy wastewater by eletctrolysis and photo-assisted electrolysis in presence of chlorides. Water Science \& Technology.

Tavares, T. C. E. (2012) Doenças crônicas não transmissíveis: prevenção e controle dos fatores de riscos. Trabalho de Conclusão de Curso (Bacharelado em Enfermagem) - Universidade Federal de Campina Grande, http://dspace.sti.ufcg.edu.br:8080/jspui/handle/riufcg/9751 >>

World Health Organization (2003). Diet, nutrition and the prevention of chronic diseases: report of a joint WHO/FAO expert consultation. WHO. 
Research, Society and Development, v. 10, n. 11, e134101119311, 2021

(CC BY 4.0) | ISSN 2525-3409 | DOI: http://dx.doi.org/10.33448/rsd-v10i11.19311

Pereira, A. S. et al. (2018). Metodologia da pesquisa cientifica. UFSM. https://repositorio.ufsm.br/bitstream/handle/1/15824/Lic_Computacao_MetodologiaPesquisa-Cientifica.pdf?sequence $=1$

Silva, J. M. et al. (2019). Qualidade microbiológica de alimentos in natura minimamente processados. Global Science and Technology. https://d1wqtxts1 xzle7.cloudfront.net/59498506/QUALIDADE_MICROBIOLOGICA_DE_ALIMENTOS_IN_NATURA_MINIMAMENTE_PROCESSAD OS20190603-83261-c5jmbp-with-cover-page-v2.pdf?Expires=1629553138\&Signature=CKJX69EnN nYZiisyaoVBGEf3hCcFF2SA6ViPZECzZxt7T $\sim$ HjY aoDSiUGnsj0K6jjps5Imq6URY1YKHQR6Tjsp3kZphmX58cbLpVHWyFOQllqINjosSvoVQ4L8KubYjf2DJWguItWScT9xkJ1w17EbO LmKvfhCs9nI63aK YU7ZiDr7 kLf9tklBeUGkAJaX2X41RrLxImQbDYVvIzkGRneiQ09Tegn2pGn4BOnCv1UixX7LiQ0R0BaG2a34FjWOQRWptlyDTCmx Vt-v-MC7 AHsI5h3a2CLkFbuRUIUgPuREp7QN2eETFHzQoFTkH74G 8hlWr 6bb09zidNeCOJQ_\&Key-Pair-Id=APKAJLOHF5GGSLRBV4ZA

Berno, N. D. et al. (2020). Perfil de consumidor de frutas e hortaliças durante a quarentena (Pandemia COVID-19). Revista Iberoamericana de Tecnologia Postcosecha, México. https://www.redalyc.org/jatsRepo/813/81363356001/81363356001.pdf

Oliveira, L. V. et al. (2021). Modificações dos Hábitos Alimentares Relacionados à Pandemia do Covid-19: uma Revisão de Literatura. Brazilian Journal of Health Review. UNIFACISA, . https://www.brazilianjournals.com/index.php/BJHR/article/view/28287/22394

Souza, A. C. F. et al. (2020). Análise microbiológica de frutas e hortaliças minimamente processadas comercializadas em supermercados da cidade de Macapá - Amapá. Research, Society and Development. https://www.rsdjournal.org/index.php/rsd/article/view/3751/3873

Nações Unidas Brasil (2020). Ano Internacional das Frutas e Vegetais: diversidade dos alimentos é essencial para alimentação. https://brasil.un.org/ptbr/105688-ano-internacional-das-frutas-e-vegetais-diversidade-dos-alimentos-e-essencial-para

Franco, L. S. V. (2019). Estudo de Armazenamento de Bananas Tratadas por Luz Ultravioleta (UV-C). Trabalho de conclusão de curso - UTFPR, Paraná. http://repositorio.roca.utfpr.edu.br/jspui/bitstream/1/16333/1/bananastratadasluzultravioleta.pdf

Moraes, I. P. et al. (2021). Tratamentos de morangos por radiação UV-C emitidos por lâmpadas de LED. Brazilian Journal of Development. Universidade Tecnológica Federal do Pará - UTFPI. https://www.brazilianjournals.com/index.php/BRJD/article/view/27995/22155. 